\title{
Responsible Ferry, Happy Employees, and Quality Services: The Study of Fair Transport in the Ferry Industry
}

\author{
Carmen Sum \\ Division of Business and Hospitality Management, College of Professional and \\ Continuing Education, The Hong Kong Polytechnic University \\ carmen.sum@cpce-polyu.edu.hk \\ Yui-yip Lau \\ Division of Business and Hospitality Management, College of Professional and \\ Continuing Education, The Hong Kong Polytechnic University \\ yuiyip.lau@cpce-polyu.edu.hk \\ Cristina Dragomir \\ Management in Transports, Constanta Maritime University, Constanta, \\ Romania \\ cristina.dragomir@cmu-edu.eu
}

\begin{abstract}
In the context of ferry industry, fair transport is a new concept and under-researched in the academic research and industrial practitioners. The ferry operators overlook responsible ferry, happy employees, and quality services are crucial to align with the United Nations Sustainable Development Goals. The role of fair transport is still ambiguous and unawareness of the society. Also, the government bodies, policymakers, and international organizations implement ineffective measures to support the idea of fair transport in a ferry industry. The paper mainly review the current ferry industry context for the new fair transport concept, and investigate the key roles of ferry operators and international organizations in the fair transport.
\end{abstract}

Keywords. Ferry industry, fair transport, United Nations Sustainable Development Goals.

\section{Background}

Fair transport becomes a hot topic in the ferry industry. International Transport Workers Federation (ITF) and the European Transport Workers' Federation (ETF) are both motivating the fair transport to stop social dumping in the industry. Workers and seafarers are not treated fairly. They have to work in violent and dangerous work conditions. Excessive and anti-social working hours, as well as exploitation, unfair, and hyperflexible contracts, are common among workers. This phenomenon happens in different countries, especially in Europe [1]. Transport workers and unions are fighting against this unfair treatment through demos, events, and protests. Employers have to step up and assume more responsibility to treat their employees in a fair and accountable way. 
Ferries have to provide safe and decent work conditions, adopt ethical employment practices, and show sincerity to seafarers. The policies and rules for fair transport should cover physical (e.g., establish 'permit to work' system decreases the risk of accidents onboard ship) (source: www.gov.uk), mental (e.g., coordinate with church and the marine club to reduce the seafarers in worry, confusion, disorientation, intrusive thoughts and images, self-blame) [10], and ethical (e.g., code of ethics covering discrimination or harassment against seafarer) [9] aspects for seafarers. Also, the management has to prepare emergency policies and action plans to manage crises and risks. The possible policies and rules of fair transport in the ferry industry will be discussed.

Companies may have hesitation to adopt fair transport because of the additional costs and resources required. This practice, however, would only bring benefits to the ferries. Taking the service-profit chain concept developed by Heskett, Jones, Loveman, Sasser \& Schlesinger [2] [3], happy customers depend on the quality services provided by happy employees, and that is driven by the internal service quality. In short, a responsible employer providing quality and sufficient support for employees would enjoy revenue growth and profitability. This paper will adopt the service-profit chain concept to explain the possible benefits brought from the adoption of fair transport.

For ensuring the successful implementation of fair transport, there are three critical conditions involved: commitment, communication, and responsibilities. These conditions are not restricted to the employer side, but also the employee aspect. Both parties have to be well prepared for the planning and execution of fair transport in their companies. The conditions, the possible policies and rules, as well as the benefits of fair transport will be explained one by one in the following sections.

\section{Conditions of fair transport}

Fair transport requires commitment from every employee in an organization, from the top management to the front line staff. The senior management should take the initiative role to plan and design work policies for ensuring health and safety. They have to be committed to providing safe and healthy work conditions, as well as precaution measures for all workers. About the employees, their commitment to follow the rules and guidelines stated in work policies is necessary. If they fail to follow, they may suffer from injuries and health problems. For ensuring employees' engagement, companies have to seek their suggestions for the work policies and guidelines. Input from employees at different levels and departments within the organization is needed, and that requires the availability of communication channels.

The second condition is the formalized communication channels. The communication platforms should be available for every employee to facilitate the solicitation of comments and suggestions regarding safety and health issues at work. Feedback from employees is an important input for drafting work policies and environments appropriate for them. The collection of ideas and suggestions also ensures a greater dedication from employees to comply with the rules and regulations set for a safe and healthy work environment. Two-way and continuous communication between the employer and employees should be maintained.

The third condition is the responsibilities of every party. Ferries, as employers, have to be responsible for planning, implementing, and controlling the work policies and procedures. They are accountable for designing safe and decent work conditions for the workers with target safety standards and apply accordingly. Periodic measures and control should be done to assess the quality of work conditions and the appropriateness of safe work policies. Amendments are needed if the conditions are not satisfied or do not meet the targeted safety standards. On the other hand, employees are responsible for complying with the rules and regulations listed in the workplace policies about safety and health. If workers do not follow the rules at work, they may put them at risk.

\section{Benefits of fair transport}

Fair transport may involve additional costs and resources from planning, implementation, to controlling, but the benefits gain would outweigh the investments involved. The service-profit chain concept may help clarify the benefits gained from doing fair transport for ferries. 
The service-profit chain concept has been developed for years in the marketing discipline for the service context by Hewlett et al. [2] [3]. It emphasizes the causal relationships from internal service quality to external service quality, and finally achieve revenue growth and profitability. Once an organization can manage itself well internally, it would gain a group of happy employers and a group of happy customers and finally achieve positive outcomes for itself (Figure 1).

Figure 1. The Service-profit Chain

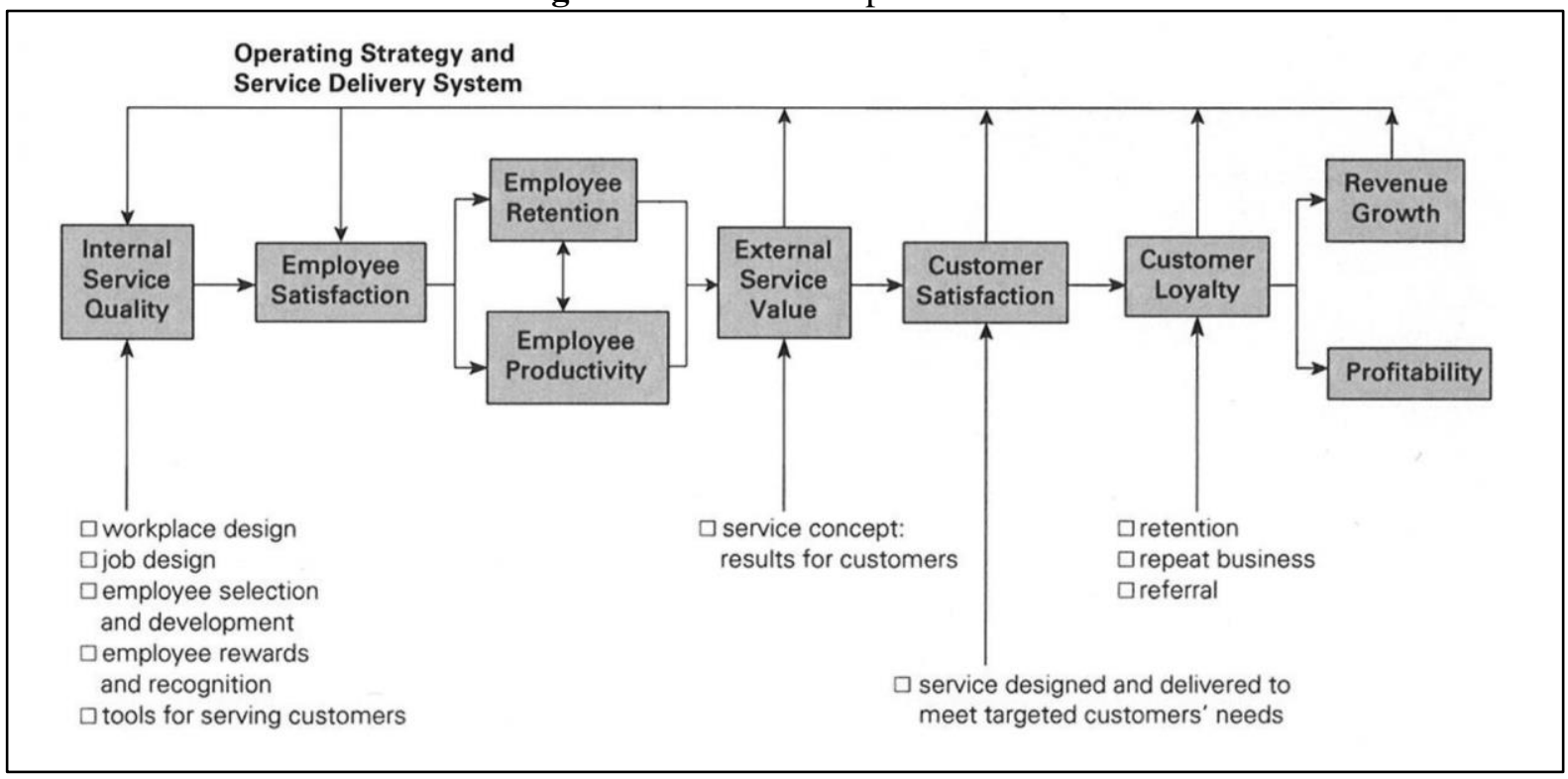

Sources: [2] [3]

As a responsible employer, the ferry should maintain internal services at a satisfactory level that benefits to the internal customers, that is employees. Examples of internal services for the ferry industry include appropriate workplace and deck design, detailed job design with remarks on dangerous activities on ferries, comprehensive personnel development system, crystal-clear promotion policies, equitable reward and recognition system, as well as appropriate tools for providing services on ferries. All these practices would make employees happy, and that would generate greater productivity and retention at work. When employees' loyalty is sustained, they would be more engaged in their work and then produce better services for external customers. If customers are satisfied with the services, they would be happier and more loyal to the company. Loyal customers could increase revenue growth and profitability for the company.

How could loyal customers generate revenue growth and profitability for the ferries? [8] elaborated on the possible sources of profit from loyal customers (Figure 2). Other than the base profit earned from a customer, we could gain profits from different aspects.

First, ferries could earn more profits from increased consumption and higher balances. Loyal customers have a higher intention to consume more services from a reliable supplier. Their switching intention is lower than other customers. The greater the loyalty, the more the sales obtained.

Second, loyal customers could be communicated and promoted through economic and effective communication channels, like emails and direct marketing. More profits could, therefore, be generated by reduced advertising and operation costs. Also, a 5\% reduction in customer churn rate would increase profits by $25 \%$ to $95 \%$ depending on the industrial nature.

The third source of profit is the referrals gain from loyal customers. Positive word-of-mouth could be obtained from loyal customers. When they are satisfied with the services, they not only keep consuming services but also spread positive word-of-mouth to their friends, peers, and relatives. The costs of recruiting new customers are then saved, as ferries could only spend promotion costs on the referral campaign and provide benefits to reward the recommendation behaviors. 
Lastly, ferries could gain more profits from price premiums. When a service provider is trustworthy, loyal customers do not mind spending more to secure quality and reliable services to minimize any consumption risks. Services are intangible, inseparable, heterogeneous, and perishable. There will be a greater risk of trying a new service provider. Usually, loyal consumers tend to repeat purchases from the same service provider.

Figure 2. The loyalty effect

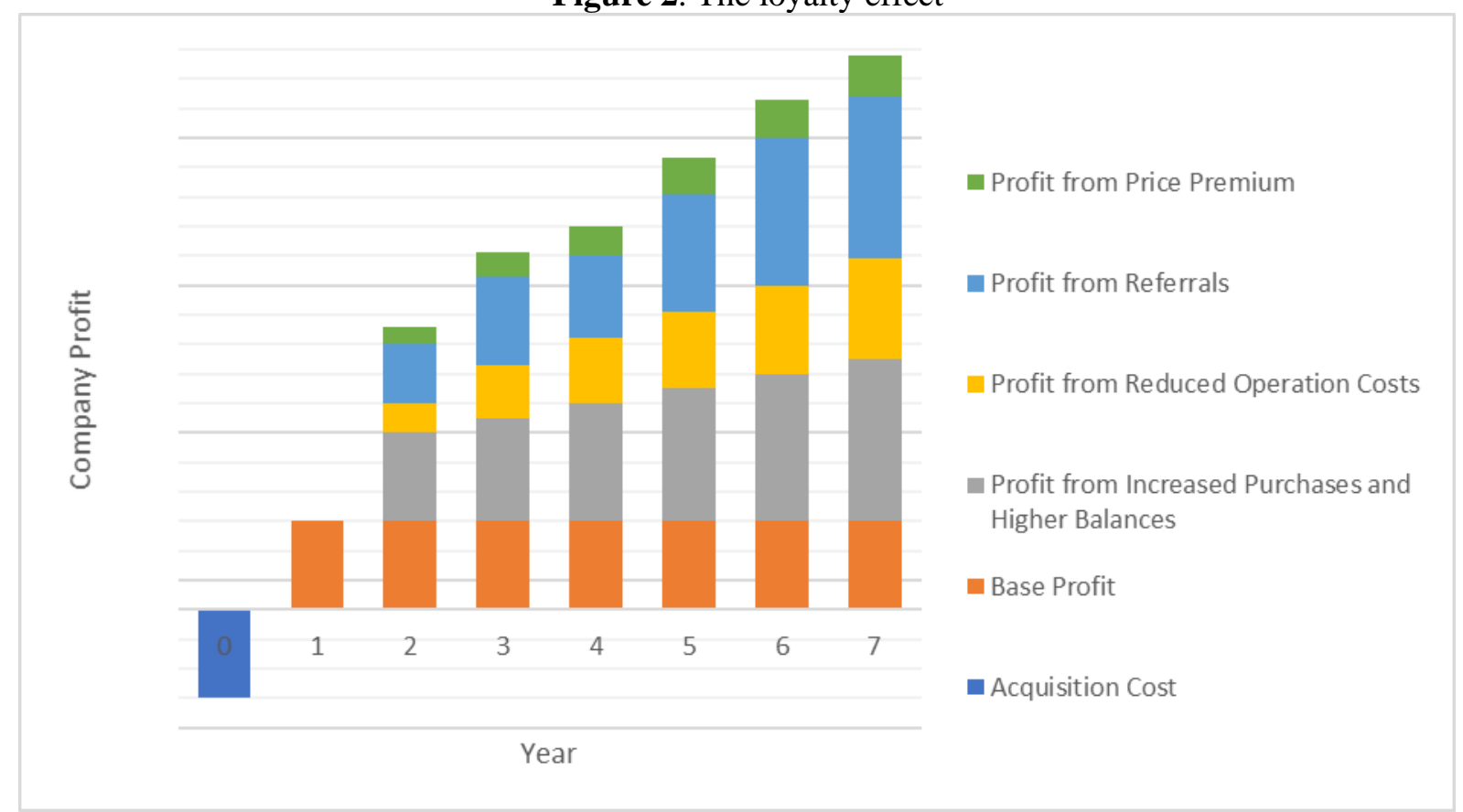

Source: [8]

\section{Conclusion}

Ferries should consider adopting fair transport in the industry. It is good for the company and its employees. The ferry industry needs to comply the policies and rules with the International Labour Organization (ILO) [7]. The ILO addressed that "the basic aims of the MLC, 2006, are to ensure comprehensive worldwide protection of the rights of seafarers and to establish a level playing field for member States and ship owners committed to providing decent working and living conditions for seafarers" [5, pp. 6]. Specially, the ILO [4, page 4) concerned about a new implementation mechanism to make sure that seafarers' working and living conditions fulfil its requirement of 'decent work ... in conditions of freedom, equity, security and human dignity'. However, [7] critized that majority of seafarers indicated the living and working conditions still far from their expectations even if ILO set up a series of laws and regulations. Furthermore, fatal ferry accidents still happened since 1900. Over $80 \%$ of ferry accidents have arisen from the human error. Although the International Maritime Organization (IMO) introduced Safety of Lives at Sea (SOLAS), some ferry operators decide to conduct the flag registration in the loose countries, for instance, Pamana, Liberia, Bahamas, Bermuda, to name but a few. To this end, the ferry operators are easier to avoid the safety regulations to use substandard vessels, outdated navigational equipment, and a lack of regular repair and maintenance. Clearly, seafarer is working under the unsafe and poor working conditions [6].

Fair transport may involve additional costs and resources at the beginning, but its long-term effect would be more significant. Other than the profits, ferries may gain a positive brand image because they are responsible for the employees. Many customers nowadays have the intention to consume services from a responsible company. 
The role of fair transport in ferry industry is under-researched. In this study, we provide a fair transport concept to increase the awareness among the ferry transport operators, ferry passenger, government bodies, policymakers and industrial practitioners. In the future, we will carry out a large scale of survey collect from seafarers to examine seafaring environment and ferry passengers' perception of service delivery in using ferry transport. The notion of fair transport is extremely significant for ferry operators' performance indicators and should be addressed in future research.

\section{References}

[1] European Transport Workers' Federation (2019, February 27). It's Time To Take Fair Transport Europe To the Next Level! Retrieved from https://www.etf-europe.org/its-time-totake-fair-transport-europe-to-the-next-level/

[2] Heskett, J. L., Jones, T. O., Loveman, G. W., Sasser, J., \& Schlesinger, L. A. (1994). Putting the Service-Profit Chain to Work. Harvard Business Review, 72(2), 164-170.

[3] Heskett, J. L., Jones, T. O., Loveman, G. W., Sasser, J., \& Schlesinger, L. A. (2008). Putting the Service-Profit Chain to Work. Harvard Business Review, 86(7/8), 118-129.

[4] ILO (1999). Decent work. Report of the director-general. International Labor Conference, 87th Geneva

[5] ILO. (2014). Guidelines on the training of ships' cooks, Geneva

[6] Lau, Y.Y. \& Sun, X. (2019). Identifying the trends and casual factors of passenger ferry accidents in Asia. Cruise Industry Review, 2(2), 51-73.

[7] Lau, Y.Y., \& Yip, T.L. (2017). The procurement of food on board liner ships: the role of the international labor organization. Journal of Shipping and Trade, 2(6), 1-14.

[8] Reichheld, F. F., \& Teal, T. (1996). The loyalty effect: The Hidden Force Behind Growth, Profits, and Lasting Value. Boston, Mass: Harvard Business School Press.

[9] Seafarer International LLC (2012). Seafarer Standards, USA.

[10] The American Club (2017). Caring for Seafarers' Mental Wellbeing, New York, USA. 